\title{
A SHORT OVERVIEW OF THE WORK OF ANTHROPOLOGISTS OF THE OLD ANATOMICAL THEATRE
}

\author{
Helje Kaarma \\ Centre for Physical Anthropology, University of Tartu, Estonia
}

The anthropologists of the University of Tartu have continued Juhan Aul's work in all its directions. As Juhan Aul considered it important to assess the physical development of great numbers of schoolchildren, to pay greater attention to anthropometric studies of women and regularly publish research papers on anthropology [1-5], his advice has been followed.

In order to coordinate anthropological research, Juhan Aul founded the Anthropology Section of the Estonian Naturalists' Society. Its 70 years of activities have been described by J. Kasmel and T. Kasmel [9, 10].

When the Republic of Estonia had regained its independence, it became possible, in 1993, to establish the Centre for Physical Anthropology at the Institute of Anatomy of the University of Tartu. The fifteen years of activities of the Centre have been described by $\mathrm{H}$. Kaarma [8].

In 1995, financed by the Ministry of Social Affairs of the Republic of Estonia, the Estonian Anthropometric Register was founded. At present, the register is located at the Centre for Physical Anthropology. It contains more than 100,000 units of anthropometric data on Estonians' body build.

Large-scale detailed anthropometric studies of schoolchildren, adult men and women and thorough statistical analysis of data under the supervision of Emeritus Professor Ene-Margit Tiit have enabled us to solve the problem of schoolchildren's, conscripts' and women's body structure, of inclusion of classical constitutional types into the general structure. It became clear that there exists a statistically significantly correlated system of anthropometric variables where the leading variables are height and weight. Changes in relations between height 
and weight lead to systematic changes in length, breadth and depth measurements, circumferences, proportions and body composition characteristics. Classical types like pycnics and leptosomes also belong to this system, and changes in their body build are also related to changes in relations between their height and weight. Based on the above-mentioned, the anthropologists of Tartu created a five-class classification of body build. The latter has been successfully applied to classify the anthropometric variables of young women, conscripts, and schoolchildren aged $7-18$ years $[6,7,11,12]$.

C. Raschka presented this classification in his book Sportanthropologie [16] as a new Estonian system in constitutional typology.

The body build structure system created in Estonia can be proposed to physicians and health promoters who can use body build data for analysing the data of their speciality.

The Centre for Physical Anthropology has also taken care of compiling height and weight norms of adult Estonian men and women. The corresponding norms have been published [15] and, based on them, the limits of the five-class height-weight classification for each annual age group of men and women have been presented [13]. We recommend this classification to family physicians and specialists on different diseases for comparative classification of their patients' body build data.

The anthropologists of the Old Anatomical Theatre have also compiled the most recent height-weight norms of Estonian schoolchildren which date from 2006-2009 [14]. They have been discussed in comparison with the previous norms of 1998 . These will also be used to create somatotypic height-weight classifications for 7-18-year-old boys and girls. These will be given to the Ministry of Social Affairs, family physicians, and school doctors and nurses for use. Summing up what has been said above, we can confirm that the anthropologists of Tartu are ready to continue their current trends of research and cooperate with Latvian and Lithuanian colleagues.

\section{REFERENCES}

1. Aul J. (1938) Anthropological research in Estonia until now and its future prospects. Strengthening the independent statehood. Collection of Raimla Student Society. Tartu, ÜS Raimla kirjastus, Tartu, 74-101 (in Estonian). 
2. Aul, J. M. (1964) Anthropology of Estonians. Transactions of the University of Tartu. Vol. 158. Tartu (in Russian).

3. Aul, J. (1974) Tables for Assessment of Physical Development of Estonian School Students. Tallinn: Valgus (in Estonian).

4. Aul, J. (1977) Anthropology of Estonian Women. Transactions of the University of Tartu. Issue 438, Papers on Anthropology III, Tartu, 5103 (in Estonian).

5. Aul J. (1964) Eestlaste antropoloogia.

6. Kaarma H. (1995) Complex statistical characterization of women's body measurements. Anthropologischer Anzeiger, 53(3), 239-144.

7. Kaarma H., Stamm R., Kasmel J., Koskel S. (1999) Body build classification for ordinary schoolgirls (aged 7-18) years and volleyball girls (aged 13-16 years). Anthropologischer Anzeiger, 63(1), 77-92.

8. Kaarma H. (2008) A brief overview of the activities of the Centre for Physical Anthropolgy during fifteen years. Papers on Anthropology XVIII, 9-14.

9. Kasmel J., Kasmel T. (2009) Anthropology Section of the Estonian Naturalists Society. Papers on Anthropology XVIII, 14-38.

10. Kasmel J., Kasmel T. (2010) Seventy years of the Anthropology Section of the Estonian Naturalists' Society (Part II). Papers on Anthropology XVIII, 21-28.

11. Lintsi M., Kaarma H. (2003) Five-class height-weight model for systematization of seventeen-years-old recruits' anthropometric data. Anthropologischer Anzeiger, 62(4), 435-443.

12. Kasmel J., Kaarma H., Saluste L., Lintsi M., Veldre G., Koskel S. (2010) Modern Physical Anthropology in Estonia. The Mankind Quarterly, Vol. L, 4, 376-384.

13. Kaarma H., Saluste L., Lintsi M., Kasmel J., Veldre G., Tiit E.-M., Koskel S., Arend A. (2008) Height and weight norms for adult Estonian men and women (aged 20-70 years). Papers on Anthropology XVII.

14. Koskel S., Tiit E.-M., Kaarma H. (2010) Changes in Estonian schoolstudents' height and weight in the last ten years. Papers on Anthropology XIX, 211-229.

15. Lõpparuanne Tartu Ülikooli Füüsilise Antropoloogia Keskuse ja Tervise Arengu Instituudi vahel 28.07.2005 a. sõlmitud lepingu kohta. Tartu, 2005.

16. Raschka C. (2006) Sportanthropologie. Köln: Sportverlag, Strauss, 219-220. 